\title{
DAMPAK PANDEMI CORONAVIRUS DISEASE (COVID-19) DALAM PERSPEKTIF HUKUM DI ERA DIGITAL
}

\author{
Jeni Danurahman*, Eny Kusdarini \\ Program Magister Pendidikan Pancasila \& Kewarganegaraan, Fakultas Ilmu Sosial \\ Universitas Negeri Yogyakarta \\ J1. Colombo No.1 Karang Malang, Yogyakarta \\ Jenidanurahman@gmail.com
}

\begin{abstract}
Indonesia is known as a mixed legal system, the current social changes are strongly influenced by the development of modern countries, namely fundamental developments regarding advances in technology. Humans are currently required to live everything fast, effective and efficient in carrying out all activities with the support of the rapid development of technology. The pandemic coronavirus disease (Covid-19) has an impact on all sectors in the world, including Indonesia. The government has made policies and appealed to work from home which makes all work activities done at home by utilizing technology as well as efforts to break the chain of the spread of Covid-19. Therefore, we need modern laws that are based on the dynamics of the needs of society in this digital era because they will change the order of life in society, nation and state.
\end{abstract}

Keywords: Modern Law; Pandemic Coronavirus Disease; Digital Era.

\begin{abstract}
Abstrak
Indonesia dikenal dengan sistem hukum campuran, perubahan-perubahan sosial yang terjadi saat ini dipengaruhi kuat oleh pembangunan negara-negara modern, yaitu perkembangan mendasar mengenai kemajuan akan teknologi. Manusia saat ini dituntut untuk hidup segala sesuatu serba cepat efektif dan efisien dalam mengerjakan segala aktivitas dengan dukungan pesatnya Teknologi. Wabah pandemi coronavirus disease (Covid-19) berdampak pada seluruh sektor di dunia tak terkecuali di Indonesia. Pemerintah sudah membuat kebijakan dan menghimbau untuk work from home yang membuat seluruh aktivitas pekerjaan dikerjakan di rumah dengan memanfaatkan teknologi sekaligus upaya untuk memutus rantai penyebaran Covid-19. Maka dari itu perlu hukum modern yang didasarkan pada dinamika tentang kebutuhan masyarakat di era digital ini karena akan merubah tatanan kehidupan bermasyarakat, berbangsa dan bernegara.
\end{abstract}

Kata Kunci: Hukum Modern; Pandemi Coronavirus Disease; Era Digital.

\section{A. Pendahuluan}

Hukum modern dapat dimaknai sebagai suatu landasan pembaruan di bidang peraturan perundang-perundangan yang dapat disesuaikan dengan kebutuhan hukum bangsa Indonesia saat ini. Dalam hal ini Indonesia menganut sistem hukum campuran, ada tiga hukum yang mendominasi hukum di Indonesia yakni sistem hukum yang dominan ke arah negara barat, kemudian sistem hukum menjunjung tinggi adat istiadat, serta sistem hukum yang berpedoman pada agama islam (Umar, 2014). Perubahan yang terjadi saat ini berpengaruh kuat pada pembangunan di kawasan negara-negara modern, yaitu dapat dilihat dari segi kemajuan teknologi, industri, serta perluasan sistem kapital yang terjadi pada era ini. Di era ini standar kemajuan suatu negara dapat diukur dari ketangkasan suatu negara dalam menciptakan atau menggunakan suatu 
teknologi yang dapat dimanfaatkan oleh manusia. Segala bentuk aktivitas kini di bantu dengan teknologi bahkan dapat dikatakan masyarakat saat ini ketergantungan akan teknologi. Apalagi dengan kondisi saat ini, ketika wabah pandemi Covid-19 ini muncul, segala bentuk kegiatan maupun aktivitas dilakukan dengan alat bantu teknologi, elektronik, maupun aplikasi yang kemudian hal tersebut menjadi solusi dalam upaya menunjang kebutuhan manusia. Di setiap segi kehidupan saat ini sangatlah bergantung pada teknologi, apalagi dengan pemberlakuan social distancing, work from home, dirumah saja mengubah segalanya ke arah digital. Dengan keadaan pemberlakuan kebijakan tersebut berdampak pada seluruh segi dan tatanan kehidupan, seperti segi pendidikan, politik, sosial, ekonomi, budaya dan lain sebagainya. Saat ini segala bentuk aktivitas ditopang penuh oleh teknologi seperti halnya dari segi pendidikan, aktivitas belajar mengajar saat ini diberhentikan untuk sementara yang kemudian diganti dengan sistem daring (dalam jaringan) dengan memanfaatkan akses internet, software (aplikasi), web, dan juga gadget/laptop. Sama halnya, dalam segi ekonomi saat ini, segala bentuk transaksi dilakukan secara online dengan menggunakan teknologi, hal tersebut juga berdampak maraknya bisnis online dan jual beli online dengan segala risiko yang akan didapatkan, bahkan ada beberapa situs jual beli online ilegal, yang tidak jelas asal-usulnya. Dengan mempertimbangkan perubahan serta dinamika kehidupan saat ini juga berpengaruh terhadap perubahan hukumnya, pembangunan hukum berkarakter modern yang dapat memuat segala ketentuanketentuan yang disesuaikan dengan situasi dan kondisi saat ini.

Pembangunan hukum yang berkarakter modern didasarkan pada dinamika kondisi suatu masyarakat. Faozi (2018) berpendapat bahwa masyarakat Indonesia saat ini dapat dikatakan masyarakat yang mengarah pada modernisasi, maka dari itu perlu adanya hukum yang berkarakter modern. Hal tersebut perlu dilakukan agar masyarakat memiliki payung hukum yang jelas dalam segala bentuk aktivitas yang akan meningkatkan taraf kesejahteraan hidup suatu masyarakat yang dapat menjangkau secara massal. Proses modernisasi seperti halnya penggunaan teknologi dengan baik, benar, dan bijak dalam segala bentuk aktivitas digital telah menimbulkan perubahan-perubahan dari segi kehidupan masyarakat. Selain itu pengaruh globalisasi yang bersifat transnasional juga dipadukan dengan pesatnya perkembangan teknologi saat ini, mengubah segala aspek kehidupan manusia secara global terutama di Indonesia. Menurut Nuh (2012) menyatakan bahwa pemerintahan yang baik dapat diwujudkan dengan sistem pemerintahan yang merefleksikan tatanan hukum yang reponsif serta dapat menyesuaikan dengan kehendak rakyat. Oleh karena itu seharusnya pemerintah bertanggungjawab untuk dapat membuat suatu tatanan hukum yang disesuaikan dengan situasi dan kondisi yang diperlukan oleh masyarakat.

Sebagai respon dari perubahan dan perkembangan zaman saat ini juga hadirnya teknologi informasi yang berdampak timbulnya permasalahan-permasalahan baru dalam kehidupan bermasyarakat, perkembangan ilmu pengetahuan dan teknologi ternyata telah membawa dampak dalam perkembangan hukum khususnya tentang masalah perbuatan yang mengarah pada tindak pidana di dunia maya (Mulasari, 2012). Padahal kini segala aktivitas seperti komunikasi, transaksi, rapat dan lain sebagainya dilakukan secara online dengan menggunakan alat bantu elektronik, banyak organisasi, kelompok masyarakat, serta pemerintahan yang melakukan perubahan ke arah paradigma baru dengan memanfaatkan teknologi yang ada guna mempertahankan salah satunya adalah keberadaan demokrasi dalam negara. Dengan melihat kondisi saat ini serta pemberlakuan social distancing di seluruh lapisan masyarakat keberadaan hukum amat sangat dibutuhkan agar pemberlakuan kebijakan tersebut dapat dilaksanakan dan dipahami oleh seluruh 
lapisan masyarakat (Tedeschi, 2020). Pesatnya ilmu pengetahuan dan teknologi serta mempertimbangkan situasi dan kondisi saat ini memunculkan suatu gagasan inovasi yang dinamakan e-democracy sebagai respon dari perkembangan tersebut. Keterlibatan media elektronik dalam sistem demokrasi dikenal dengan istilah $e$ democracy yang kini telah menjadi isu penting dan dikembangkan oleh banyak negara maju di dunia, terutama sejak awal 1990-an, seiring dengan perkembangan teknologi dan informasi berbasis internet (Parvez, 2008). E-democracy memiliki tujuan untuk meningkatkan struktur dan proses sistem demokrasi yang dapat diakses dengan mudah di suatu negara melalui media elektronik (Slamet et al., 2009). Edemocracy merupakan sebuah inovasi baru dalam dunia politik, yang di dalamnya juga akan muncul inovasi-inovasi lainnya yang merupakan bagian dari e-democracy seperti e-forum, e-konsultasi, e-voting, e-petisi, epanel, e-kelompok, blog, dan lain sebagainya. Hal tersebut diharapkan dapat meningkatkan partisipasi masyarakat untuk mengkaji isu-isu publik serta dapat mempermudah proses berdemokrasi yang baik dan benar di negara hukum modern yang terus mengalami perkembangan zaman, serta dengan mudah memanfaatkan keberadaan media sosial sebagai ruang publik untuk berpartisipasi secara langsung menyampaikan aspirasinya terkait dengan demokrasi yang diterapkan di dalam negara sudah sesuai dengan keinginanan rakyat atau masih perlu perbaikan.

Berdasarkan penjelasan yang telah diutarakan di atas maka penulisan ini bertujuan untuk mengetahui dampak pandemi coronavirus disease (Covid-19) dalam perspektif hukum di era digital. Karena kita ketahui bersama bahwa wabah pandemi coronavirus disease (Covid-19) ini berdampak pada seluruh aspek kehidupan termasuk perspektif hukum digital padahal di situasi sekarang keberadaan teknologi informasi dan komunikasi berbasis digital amat sangat diperlukan untuk membantu serta menunjang segala aktivitas manusia, namun belum ada payung hukum yang jelas mengenai hukum era digital. Adapun pendekatan dalam penelitian ini menggunakan pendekatan kualitatif yaitu systematic literature review dengan mengumpulkan serta membandingkan dari beberapa jurnal yang telah disusun diseleksi kemudian dilakukan kategorisasi sehingga memuat informasi yang akuntabel dan valid.

\section{B. Pembahasan}

\section{Pemahaman Hukum di Negara Hukum Modern}

Membahas mengenai tata aturan hukum yang berlaku di Indonesia berarti membahas mengenai sistematika berlakunya sistem hukum di Indonesia. Dengan demikian, secara sistematik berarti hukum dilihat sebagai suatu kesatuan yang utuh, meliputi unsur-unsur, sub-sub sistem maupun komponen-komponen yang saling berkaitan satu sama lain dan juga saling mempengaruhi satu sama lain sehingga berdampak menguatkan ataupun melemahkan antara satu dengan yang lainnya (Umar, 2014). Sistem hukum yang berlaku di Indonesia bersumber dari tiga sumber hukum yakni sistem hukum yang menjunjung tinggi mengenai nilai-nilai adat istiadat, kemudian sistem hukum yang berpedoman ke negara barat, serta yang terakhir yaitu sistem hukum agama Islam. Di Indonesia sendiri menganut sistem campuran yakni mengolaborasi ketiga hukum yang menjadi sumber hukum yang diakui oleh Indonesia (Ali, 2009). Dalam perjalanan sejak pemerintahan Indonesia dikendalikan oleh Pemerintahan Belanda, pada tahun 1937 pemerintahan belanda membuat suatu kebijakan pemberlakuan Undang-Undang Syariat Islam karena mayoritas penduduk Indonesia beragama Islam, setelah itu pemerintahan belanda memberlakukan hukum adat dalam upaya memperluas bidang sistem hukum yang telah berlaku dengan mengodifikasikan hukum adat, hukum islam dipadukan dengan hukum barat (Prins, 1951). Namun dalam realitasnya, dalam pembentukan hukum (law 
making) terkadang ada unsur kepentingan satu kelompok tertentu, penyimpangan dan penyelewengan, namun seharusnya dalam pembentukan hukum perlu mempertimbangan pada kebutuhan masyarakat. Dengan adanya pengaruh globalisasi dan perkembangan teknologi yang pesat di era digital mengakibatkan kedilemaan bagi pembuat kebiajakan hukum untuk menciptakan kesejahteraan rakyat. Terjadi pertentangan mengenai pelaksanaan undang-undang liberal yang hal tersebut mengakibatkan perdebatan dari berbagai kelompok kepentingan. Upaya untuk menciptakan kesejahteraan ekonomi tidak lepas dari kedaulatan negara dalam menentukan kebijakan kesejahteraan ekonomi dalam bentuk ekonomi.

Kebutuhan akan peraturan yang jelas mengenai suatu hal akan berdampak pada kondisi suatu masyarakat. Di era revolusi industri 4.0 saat ini, segala bentuk aktivitas telah didukung oleh teknologi. Menurut Wibawa (2016) berpendapat bahwa manusia dalam peradaban modern menuntut segala sesuatu serba cepat, efektif dan efisien, maka dari itu perlu adanya terobosan, perubahan paradigma, fleksibilitas, yuridiksi universal sehingga hukum modern dapat berlaku di dunia maya/ digital. Dari seluruh segi kehidupan seperti segi pendidikan, politik, ekonomi, sosial dan lain sebagainya. Dalam segi pendidikan saat ini banyak aplikasi-aplikasi yang dapat mendukung dari kegiatan pembelajaran seperti aplikasi Ruang Guru, Zenius, Quipper dan lain sebagainya. Selain itu dari segi politik belum lama ini ada suatu gagasan yaitu edemokrasi, e-demokrasi merupakan suatu kegiatan dalam demokrasi yang didukung oleh teknologi. Sedangkan dari segi ekonomi, saat ini masyarakat sangat menggemari bisnis online, juga maraknya penyedia jasa aplikasi online seperti Shopee, Buka Lapak, Lazada dan lain sebagainya, hal tersebut diciptakan dalam upaya mendukung perekonomian Indonesia ke taraf yang lebih baik dengan memanfaatkan pesatnya teknologi. Kemudian dari segi sosial, perubahan kehidupan sosial saat ini didukung oleh media sosial seperti Facebook, Twitter, Instagram, dan lain sebagainya, hal tersebut diciptakan dalam upaya untuk memudahkan manusia dalam berinteraksi dengan bantuan teknologi sehingga terjadi interaksi virtual.

\section{Tantangan Hukum Indonesia di Era Digital}

Pesatnya teknologi ke arah serba digital menjadikan sebuah tantangan bagi masyarakat, pemerintahan, juga hukum yang berlaku di Indonesia. Dalam situasi pesatnya perkembangan teknologi informasi dan komunikasi di era digital seperti ini, manusia memiliki tren hidup trendi yang dapat mengubah struktur dan tatanan manusia dalam bermasyarakat, berbangsa, dan bernegara (Setiawan, 2017). Dalam realita kehidupan saat ini manusia memiliki kecenderungan untuk menggunakan media eletronik maupun teknologi dalam aktivitas sehari-sehari bahkan dapat dikatakan manusia ketergantungan akan teknologi. Teknologi dalam hal ini dapat dijadikan sebagai media yang dapat mendukung pemenuhan kebutuhan dan keperluan manusia. Penggunaan teknologi saat ini menjadi alat bantu manusia dalam upaya mempermudah setiap kegiatan aktivitas yang itu berupa tugas maupun suatu pekerjaan manusia dengan pemberlakuan social distancing dalam upaya memutus rantai penyebaran Covid-19 telah mengintensifkan pengtingnya penggunaan teknologi digital khususnya media komunikasi untuk berkomunikasi dengan orang lain (Watson et al., 2020). Peradaban manusia secara tidak sadar telah mengubah manusia memasuki era digital. Namun dengan adanya teknologi tentu ada dampak positif maupun negatif yang ditimbulkan. Sehingga hal tersebut menjadi tantangan terkini sekaligus berdampak terhadap seluruh aspek, segi, bidang kehidupan seperti dalam hal politik, ekonomi, sosial, budaya, pertahanan, keamanan, industri, bahkan dalam sektor pendidikan. Dengan pesatnya teknologi yang semakin canggih menyebabkan pergeseran/perubahan di skala 
dunia bahkan di Indonesia. Namun jika melihat sisi yang lain manusia telah dimudahkan dalam melakukan setiap akses yang dibutuhkan dengan melalui banyak cara dan ketersediaan informasi yang terbuka. Namun dampak negatif dari adanya teknologi menjadi sebuah ancaman khususnya bagi masyarakat Indonesia. Seperti halnya tindak kejahatan yang saat ini terfasilitasi dengan adanya teknologi informasi, game online yang akan menyebabkan kecanduan, pornografi, serta pelanggaran hak cipta mudah dilakukan, seperti itulah dampak negatif dari adanya teknologi.

Indonesia yang dinobatkan sebagai negara maju baru-baru ini, teknologi dapat menjadi tolak ukur kemajuan suatu negara dan teknologi informasi dan komunikasi digital mampu mendorong berbagai sektor dalam upaya memajukan serta menyejahterakan Indonesia termasuk dari segi infrastruktur dan hukum. Apalagi saat ini dengan adanya pandemi Covid-19 segala bentuk aktivitas manusia dibatasi dengan pemberlakuan social distancing dan menjaga tetap di rumah saja, membuat segala bentuk transaksi, aktivitas, berkerja, belajar, belanja dan lain sebagainya dilakukan secara online, banyak penyedia jasa jual beli ini online seperti Shopee, Lazada, Bukalapak dan lain sebagainya yang dapat memudahkan konsumen dalam membeli barang. Namun banyak transaksi jual beli yang mengabaikan kewajiban administrasi, pajak dan hukum keperdataan yang telah diatur oleh negara. Bahkan beberapa di antaranya tidak perlu memiliki perusahaan resmi, namun cukup memiliki blog termasuk juga dalam melakukan jual beli. Berbagai dampak dari perkembangan teknologi menjadi tantangan bagi Indonesia untuk dapat mengatur serta membuat hukum di era digital yang tidak mengenal batas negara. Hukum dalam hal ini dituntut untuk dapat melindungi hak-hak warga negaranya dalam dalam segala bentuk aktivitas di dunia maya, seperti penipuan di e-commerce, jaminan perlindungan hak atas kekayaan intelektual dan terhindar dari segala bentuk konten yang menyesatkan. Konteks keberlakuan hukum nasional yang sektoral memerlukan reorientasi secara global, karena internet tidak hanya menghubungkan satu orang dengan orang dalam ruang lingkup satu negara, namun seantero bumi. Freckelton (2020) mengemukakan bahwa di masa pandemi ini banyak masyarakat merasa takut, cemas, atas kondisi yang terjadi, terlebih banyak informasi dari media massa yang berbasis online seperti media sosial yang menyebarkan kekhawatiran dengan memberikan informasi-informasi palsu yang membuat masyarakat menjadi resah dan khawatir akan kondisi yang terjadi, dengan menyebarkan informasi yang tidak dapat dipertanggungjawabkan akan keaslian informasi tersebut. Perlu adanya pengedukasian serta penegakan hukum juga serta regulasi yang jelas mengenai aturan itu terlebih dalam konteks penyebaran informasi di dunia maya, namun hingga kini upaya upaya dari kebijakan regulasi terkait dengan penyebaran informasi yang tidak jelas sulit untuk dilakukan. Pandemi ini tentu berdampak pada psikologi masyarakat yang membuat masyarakat mengalami kekhawatiran, kegelisahan serta keresahan yang mendalam. Tentu kondisi tersebut harus menjadi perhatian khusus bagi pemerintah terlebih untuk para pemangku kebijakan dalam hal ini untuk memberlakukan aturan yang jelas mengenai pemberian informasi khususnya di dunia maya agar tidak menimbulkan kekhawatiran dan keresahan bagi masyarakat. Setiap aktivitas manusia kini didukung oleh teknologi, seperti halnya aktivitas belajar online, belanja online, perbankan secara online, pemberlakuan penerapan e-tilang, dan $e$-voting yang telah terjadi di Kabupaten Sleman Daerah Istimewa Yogyakarta. Kehidupan kini memang telah mengalami pergeseran, jika demikian maka perlu payung hukum yang jelas yang mengatur segala ketentuan aktivitas maupun kegiatan tersebut untuk meminimalisir adanya penyalahgunaan di era digital seperti ini.

Ketidakmampuan hukum modern dalam menjangkau masalah-masalah yang terjadi 
di atas membuat dunia maya dianggap sebagai dunia tanpa hukum. Dengan pesatnya teknologi saat ini akan mengubah tatanan ekonomi, politik, budaya akses teknologi informasi dengan bantuan jaringan internet secara global, yang dapat melintasi batas negara (Walby, 2003). Djalante et al., (2020) mengemukakan bahwa dunia saat ini berada dalam situasi darurat karena adanya Covid-19 yang menjadi pandemi skala global, dijelaskan bahwa Indonesia diperkirakan akan terpengaruh secara signifikan dalam waktu yang lebih lama, mengingat penduduk Indonesia masuk pada posisi keempat dunia dengan penduduk terbanyak di dunia. Tanggapan mengenai pemerintah terhadap adanya Covid-19 pada bulan Januari sampai dengan Maret 2020. Dengan memperoleh berupa hasil bahwa Pemerintah Indonesia harus tanggap dalam menyikapi pandemi Covid-19 dan mengutamakan pada sektor kesehatan masyarakat Indonesia, hal positif yang dapat di peroleh dengan adanya Covid-19 ini menciptakan suatu kondisi masyarakat yang peduli akan kesehatan dan lingkungannya karena dengan adanya pandemi ini setiap individu dituntut untuk hidup sehat.

Teknologi saat ini sudah telah mencakup pada seluruh bagian sektor termasuk politik, pendidikan, pemerintahan, termasuk di bidang hukum. Teknologi komunikasi informasi memfasilitasi bentukbentuk baru pembuatan kebijakan sektor publik yang didukung e-goverment yang mendukung setiap kebijakan dari $e$ democracy (Chadwick, 2003). Pada konfigurasi ulang mengenai hukum dan komputer sehingga adanya korelasi antara hukum dan teknologi informasi yang sangat pesat saat ini (Hildebrandt, 2016) hal tersebut dilakukan dalam upaya untuk menciptakan suatu kondisi yang aman, kondusif, bagi masyarakat Indonesia karena dengan adanya korelasi antara hukum dan teknologi dapat mencegah dampak negatif dari adanya teknologi, seperti halnya mengenai pelanggaran tentang hak cipta, penipuan, hoaks, judi online dan lain sebagainya yang dapat merusak moral masyarakat Indonesia. Peran pemerintah dalam hal ini sangatlah dibutuhkan, perlu adanya pengkajian yang lebih mendalam mengenai penetapan hukum digital yang berlaku di Indonesia. Undang-Undang Informasi dan Transaksi Elektronik yang diberlakukan pada tahun 2016 memang sudah baik, namun perlu adanya perbaikan mengenai pengkajian lebih mendalam karena rincian-rincian khusus yang belum terbahas dalam Undang-Undang Informasi dan Teknologi. Efektivitas penegakan hukum teknologi dan informasi adalah salah satu instrumen yang dapat digunakan untuk mengevaluasi bagaimana kinerja, tujuan, dan sasaran dari Undang-Undang Informasi dan Transaksi Elektronik dalam pengimplementasiannya.

\section{Hukum Indonesia di Tengah Pandemi Covid-19}

Dengan adanya wabah Covid-19 kondisi negara Indonesia dapat dikatakan mengkhawatirkan dan mencekam. Seluruh sektor dunia lumpuh akibat adanya wabah Covid-19 yang terjadi secara mendadak membuat seluruh negara di dunia tidak siap dalam menghadapi wabah Covid 19 ini. Dampak pandemi Covid-19 ini tidak hanya berakibat pada stabilitas sektor ekonomi, sosial, budaya, pendidikan, kesehatan, hukum, industri tetapi pada seluruh sektor termasuk pada kebijakan hukum seperti halnya di Indonesia. Dengan mempertimbangkan kondisi yang terjadi saat ini, pemerintah sudah mengimbau kepada seluruh masyarakat Indonesia untuk work from home atau bahasa yang lebih umum yaitu WFH. Tujuan adanya himbauan tersebut ialah tidak lain untuk mengurangi risiko penyebaran Covid-19.

Dengan melihat situasi dan kondisi saat ini banyak institusi-institusi pemerintah yang menjalankan kegiatannya melalui bantuan alat elektronik/teknologi. Seperti halnya gagasan yang dikeluarkan oleh Mahkamah Agung Nomor 1 Tahun 2019 berbentuk elektronik tentang Administrasi Perkara Pengadilan Secara Elektronik. Langkah tepat yang diambil oleh Mahkamah 
Agung dengan memberlakukan Pengadilan Secara Elektronik, mengingat situasi dan kondisi yang tidak memungkinkan untuk melakukan persidangan, karena hal tersebut bertentangan dengan himbauan pemerintah yang mengemukakan bahwa pemerintah mengimbau masyarakat untuk mengurangi kegiatan yang berkerumun, termasuk dalam hal ini adalah perlaksanaan sidang peradilan. Hal tersebut diperkuat oleh McIntyre et al., (2020) mengungkapkan kondisi pemberlakuan hukum dan pengadilan di Australia dilaksanakan secara online dengan membahas sejumlah struktur dan masalah sistematik yang muncul dari pelaksanaan peradilan secara online dengan mempertimbangkan masalah-masalah di ruang digital serta menjelaskan tentang keterbatasan teknologi dalam mencakup masalah-masalah yang terjadi. Selain itu di bidang pendidikan dalam hal ini membuat suatu kebijakan yang disampaikan dengan Surat Edaran Nomor 4 Tahun 2020 berbentuk elektronik tentang Pelaksanaan Kebijakan Pendidikan dalam Masa Darurat Penyebaran Coronovirus Disease (Covid19) yang berisikan bahwa dalam rangka pencegahan dan mengurangi perkembangan penyebaran Corona Virus Disease (Covid19). Pada Surat Edaran Nomor 4 Tahun 2020 yang berbentuk elektronik berisikan 6 point himbauan yang salah satunya yaitu kebijakan belajar di rumah dengan bantuan alat teknologi serta melarang kegiatan belajar mengajar di sekolah dengan tatap muka, hal tersebut dikeluarkan oleh Kemendikbud sebagai langkah untuk memutus rantai penyebaran Covid-19 yang kemudian kebijakan ditindaklanjuti oleh Gubernur, Bupati/Walikota, dalam lingkup nasional di seluruh wilayah Indonesia (Menteri Pendidikan dan Kebudayaan Republik Indonesia, 2020). Selain berdampak signifikan terhadap pelayanan hukum juga sistem pendidikan di Indonesia. Hal tersebut diperkuat oleh Elvis (2020) yang berpendapat bahwa karena adanya pandemi Covid-19 membuat proses belajar dan mengajar tidak dapat dilaksanakan secara tatap muka, melainkan dialihkan melalui suatu media alat bantu (daring). Hal ini mengakibatkan proses pembelajaran yang mengalami perubahan, termasuk penyesuaian pendidik maupun peserta didik dalam proses pembelajaran secara daring dengan menerapkan tujuh konsep pembelajaran daring dalam konteks pandemi Covid-19 yaitu pembelajaran smart, kultur populer, inovatif, kasih, adaptasi, teologi hidup, serta yang terakhir yaitu pembelajaran damai.

Pandemi Covid-19 juga berdampak signifikan terhadap perekonomian Indonesia. Indonesia menghadapi tantangan yang amat berat, pemerintah bersama otoritas keuangan dan otoritas perbankan dalam hal ini mengambil langkah-langkah luar biasa dalam menjamin kesehatan masyarakat Indonesia, menyelamatkan perekonomian skala nasional sehingga terjadi penstabilan keuangan. Pemerintah mengeluarkan Peraturan Pemerintah Pengganti Undang-Undang Republik Indonesia (2020) Nomor 1 mengenai Pemberlakukan Kebijakan Keuangan Negara serta Stabilitas Sistem Keuangan pada saat pandemi Covid-19 berlangsung. Salah satu yang diatur dalam Perppu tersebut yaitu mengenai kebijakan keuangan negara yang kemudian diatur lebih rinci oleh Kementerian Keuangan melalui Peraturan Menteri Keuangan dalam upaya menjalankan amanat tersebut, Kementerian Keuangan menerbitkan PMK Nomor 38/PMK.02/2020 tentang Pelaksanaan Kebijakan Keuangan Negara untuk Penanganan Pandemi Corona Virus Disease 2019 (Covid-19) (Menteri Keuangan Republik Indonesia, 2020). Sebegitu gentingnya penanganan dalam pandemi Covid-19 sehingga setiap institusi setiap Kementerian membuat suatu kebijakan dan mayoritas kebijakan tersebut banyak mempertimbangkan dengan memanfaatkan pesatnya teknologi saat ini. Seperti halnya di Kemendikbud membuat suatu kebijakan bahwa kegiatan belajar mengajar sekolah ditiadakan, diganti dengan pembelajaran daring (dalam jaringan) dengan memanfaatkan aplikasi seperti Ruang Guru, 
Quipper, Zenius, dan lain sebagainya dalam upaya mendukung setiap kegiatan pembelajaran sekolah, sehingga peserta didik dapat belajar dari rumah (Nasution, 2020).

Dengan keadaan seperti ini, pemanfaatan teknologi informasi merupakan sebuah solusi dalam mendukung setiap bentuk kegiatan, namun di sisi lain kurangnya perhatian pemerintah tentang peraturan yang mengatur segala bentuk aktivitas tentang teknologi informasi dan transaksi elektronik. Dalam Undang-Undang Republik Indonesia (2016) tentang Informasi dan Transaksi Elektronik yang memuat aturan mengenai informasi serta bertransaksi eketronik merupakan sebuah jembatan bagi masyarakat untuk melakukan segala aktivitas dengan elektronik dengan bantuan teknologi, namun di sisi lain banyaknya polemik, permasalahan, dalam Undang-Undang Teknologi Informasi tersebut khususnya mengenai banyaknya pasal karet yang dapat menimbulkan multitafsir yang akan berdampak pada penyalahgunaan dan bahkan dapat merugikan salah satu pihak. Namun di satu sisi dampak pandemi Covid-19 ini berakibat mengubah segala tatanan kondisi kehidupan manusia, segala aktivitas dilakukan dengan digital. Menurut Mawardi (2015) mengungkapkan bahwa hal tersebut tentu menjadi suatu permasalahan. Padahal dalam hakikatnya hukum merupakan sebuah sarana untuk mewujudkan keadilan sosial, menciptakan kesejahteraan bagi masyarakat. Dalam pengaturan tersebut terdapat petunjuk mengenai apa yang harus dilakukan mana yang boleh dan tidak boleh dilakukan, dengan harapan segala sesuatunya akan berjalan tertib, teratur, sebagaimana mestinya. Selain itu hukum dalam posisi masyarakat yang teratur tersebut, dijadikan sarana untuk mewujudkan keadilan sosial dan dapat bermanfaat bagi kehidupan masyarakat. Masyarakat akan terlindungi hak dan kewajibannya, aman dan nyaman dalam kehidupan bermasyarakat. Hukum juga dapat berfungsi sebagai penggerak pembangunan yaitu dapat membawa masyarakat ke arah yang lebih baik atau ke arah yang lebih maju (Kusumaatmadja, 1976).

Namun dalam kenyataannya dalam kehidupan masyarakat saat ini, masyarakat semakin kompleks dan telah terjadi pergeseran maupun perubahan-perubahan dalam tatanan nilai atau budaya, seperti halnya terjadi saat ini, dampak dari adanya pandemi Covid-19 telah mengubah nilainilai dan tatanan hidup masyarakat Indonesia. Bahkan hal tersebut dikatakan sebagai the new normal yang mengubah tatanan kehidupan normal yang dulu dengan yang sekarang. Dampak yang signifikan dengan adanya pandemi Covid-19 akan melumpuhkan sektor ekonomi dan kemungkinan besar apabila hal ini terus berlanjut akan mengakibatkan terjadinya krisis ekonomi, hal yang perlu dilakukan agar tidak terjadi krisis ekonomi secara nasional yaitu mencari dan mengilustrasikan implikasi-implikasi mendasar karena adanya pandemi Covid-19 yang akan menjadi solusi dari dampak Covid 19 (Drozd \& Tavares, 2020).

\section{Simpulan}

Perubahan yang terjadi saat ini berpengaruh kuat pada pembangunan di kawasan negara-negara modern, yaitu dapat dilihat dari segi kemajuan teknologi, industri, serta perluasan sistem kapital yang terjadi pada era ini. Di era ini, standar kemajuan suatu negara dapat diukur dari ketangkasan suatu negara dalam menciptakan atau menggunakan suatu teknologi yang dapat di manfaatkan oleh manusia. Masyarakat Indonesia saat ini dapat dikatakan masyarakat yang mengarah pada modernisasi, maka dari itu perlu adanya hukum yang berkarakter modern. Proses modernisasi seperti halnya penggunaan teknologi dengan baik, benar, dan bijak dalam segala bentuk aktivitas digital telah menimbulkan perubahanperubahan dari segi kehidupan masyarakat

Berbagai dampak dari perkembangan teknologi menjadi tantangan bagi Indonesia untuk dapat mengatur serta membuat hukum 
di era digital yang tidak mengenal batas negara. Seluruh sektor dunia lumpuh akibat penyebaran wabah Covid-19 yang terjadi secara mendadak membuat seluruh negara di dunia tidak siap dalam menghadapi wabah Covid 19 ini. Dengan adanya wabah Covid19 maka segala aktivitas kehidupan manusia didukung dengan Teknologi. Perlu adanya hukum yang mengatur akan teknologi dan informasi yang tepat karena hukum merupakan sarana untuk mewujudkan keadilan sosial dan dapat bermanfaat bagi kehidupan masyarakat. Namun dalam kenyataannya dalam kehidupan masyarakat saat ini, masyarakat semakin kompleks dan telah terjadi maupun perubahan-perubahan dalam tatanan nilai atau budaya, seperti halnya terjadi saat ini, dampak dari adanya pandemi Covid-19 telah mengubah nilainilai dan tatanan hidup masyarakat Indonesia.

\section{DAFTAR PUSTAKA}

Ali, A. (2009). Menguak Teori Hukum dan Teori Peradilan. Kencana.

Chadwick, A. (2003). Bringing EDemocracy Back in: Why it Matters for Future Research on E-Governance. Social Science Computer Review, 21(4), 443-455.

https://doi.org/10.1177/0894439303256

372

Djalante, R., Lassa, J., Setiamarga, D., Sudjatma, A., Indrawan, M., Haryanto, B., Mahfud, C., Sinapoy, M. S., Djalante, S., Rafliana, I., Gunawan, L. A., Surtiari, G. A. K., \& Warsilah, H. (2020). Review and analysis of current responses to COVID-19 in Indonesia: Period of January to March 2020. Progress in Disaster Science, 6(march), 100091.

https://doi.org/10.1016/j.pdisas.2020.10 0091

Drozd, L., \& Tavares, M. (2020). Responding to Covid-19: A Note. https://doi.org/10.21799/FRBP.WP.202 0.14
Elvis, M. (2020). Pedagogi di Era Digital dalam Konteks Pandemi Covid-19. Jurnal Ilmu Teologi Dan Pendidikan Agama Kristen, 1(1), 1. https://doi.org/10.25278/jitpk.v1i1.472

Faozi, S. (2018). Hukum Modern Di Tengah Perubahan Sosial Di Era Global. https://www.unisbank.ac.id/ojs/index.ph p/sendi_u/article/view/6011/1878

Freckelton QC, I. (2020). COVID-19: Fear, quackery, false representations and the law. International Journal of Law and Psychiatry, 72, 101611. https://doi.org/10.1016/j.ijlp.2020.1016 11

Hildebrandt, M. (2016). Law as Information in the Era of Data-Driven Agency. Modern Law Review, 79(1), 1-30. https://doi.org/10.1111/14682230.12165

Kusumaatmadja, M. (1976). Fungsi dan Perkembangan Hukum Dalam Pembangunan Nasional. Binacipta.

Mawardi, R., D. (2015). Fungsi Hukum Dalam Kehidupan Masyarakat. Masalah-Masalah Hukum, 44(3), 275. https://doi.org/10.14710/mmh.44.3.201 5.275-283

McIntyre, J., Olijnyk, A., \& Pender, K. (2020). Civil courts and COVID-19: Challenges and opportunities in Australia. Alternative Law Journal, 45(3), 195-201. https://doi.org/10.1177/1037969X20956 787

Menteri Keuangan Republik Indonesia. (2020). Nomor 38/PMK.02 Tentang Pelaksanaan kebijakan Keuangan Negara Untuk Penanganan Pandemi Coronavirus Disease 2019 (Covid-19).

Menteri Pendidikan dan Kebudayaan Republik Indonesia. (2020). Surat Edaran Nomor 4 Tentang Pelaksanaan Kebijakan Pendidikan dalam Masa Darurat Penyebaran Coronavirus Disease (Covid-19). 
Mulasari, L. (2012). Kebijakan Formulasi Tentang Tindak Pidana Kesusilaan Di Dunia Maya Dalam Perspektif Hukum Islam. Masalah-Masalah Hukum, 41(1), 98-109.

https://doi.org/10.14710/MMH.41.1.201 2.98-109

Nasution, M. R. (2020). Covid-19 Tidak Menjadi Hambatan Pendidikan Di Indonesia. Jurnal Pendidikan, April. https://doi.org/10.13140/RG.2.2.28543. $36005 / 1$

Nuh, M. S. (2012). Hakikat Pertanggungjawaban Pemerintah Daerah Dalam Penyelenggaraan Pemerintahan. Masalah-Masalah Hukum, 41(1), 50-58. https://doi.org/10.14710/MMH.41.1.201 2.50-58

Parvez, Z. (2008). E-Democracy from the Perspective of Local Elected Members. International Journal of Electronic Government Research, 4(3), 20-35. https://doi.org/10.4018/jegr.200807010 2

Peraturan Pemerintah Pengganti UndangUndang Republik Indonesia. (2020). Nomor 1 Tentang Kebijakan Keuangan Untuk Penanganan Pandemi Corona Virus Disease 2019 (Covid-19).

Prins, J. (1951). Adatlaw and Muslim Religious Law in Modern Indonesia. Die Welt Des Islams, 1(4), 283-300. https://doi.org/10.1163/157006051X000 23

Setiawan, W. (2017). Era Digital dan Tantangannya.

Slamet, Hamdan, A. R. bin, \& Deraman, A. (2009). E-demokrasi di indonesia, antara peluang dan hambatan pendekatan fenomenologis. Seminar
Nasional Informatika, 2009(semnasIF), 85-93.

Tedeschi, M. (2020). The body and the law across borders during the COVID-19 pandemic. Dialogues in Human Geography, 10(2), 178-181. https://doi.org/10.1177/2043820620934 234

Umar, N. (2014). Konsep Hukum Modern: Konsep Modern: Suatu Perspektif Keindonesiaan, Integrasi Sistem Hukum Agama dan Sistem Hukum Nasional. In Walisongo: Jurnal Penelitian Sosial Keagamaan (Vol. 22, Issue 1). LP2M Universitas Islam Negeri (UIN) Walisongo. https://doi.org/10.21580/WS.22.1.263

Undang-Undang Republik Indonesia. (2016). Perubahan Atas UndangUndang Nomor 11 Tahun 2008 Tentang Informasi Dan Transaksi Elektronik. UU No. 19 Tahun 2016, 1, 1-31.

Walby, S. (2003). The myth of the nationstate: Theorizing society and polities in a global era. Sociology, 37(3), 529-546. https://doi.org/10.1177/0038038503037 3008

Watson, A., Lupton, D., \& Michael, M. (2020). Enacting intimacy and sociality at a distance in the COVID-19 crisis: the sociomaterialities of home-based communication technologies. Media International Australia, $1329878 X 2096156$.

https://doi.org/10.1177/1329878X20961 568

Wibawa, I. (2016). Era Digital (Pergeseran Paradigma Dari Hukum Modern Ke Post Modernisme). Masalah-Masalah Hukum, 45(4), 285. https://doi.org/10.14710/mmh.45.4.201 6.285-291 